\title{
Pengaruh Pupuk Nitrogen dan Jarak Tanam terhadap Pertumbuhan dan Produksi Talas Belitung (Xanthosoma sagittifolium (L.) Schott)
}

\section{The Effect of Nitrogen Fertilizer and Plant Spacing on Growth and Production of Cocoyam (Xanthosoma sagittifolium (L.) Schott)}

\section{Tyas Arumsari dan Suwarto*}

Departemen Agronomi dan Hortikultura, Fakultas Pertanian, Institut Pertanian Bogor, Jalan Meranti, Kampus IPB Darmaga, Bogor 16680, Indonesia

Telp.\&Faks.62-251-8629353 e-mail agronipb@indo.net.id

*Penulis untuk korespondensi: wrtskm@yahoo.com

Disetujui : 15 Januari 2018 / Published Online 23 Januari 2018

\begin{abstract}
Cocoyam (Xanthosoma sagittifolium (L.) Schott) has a high starch content. It can be an alternative carbohydrate source besides rice. The research aimed to obtain the best of nitrogen fertilizer dosage and planting space for Cocoyam cultivation. This research was conducted at Cikabayan Teaching Farm Dramaga, Bogor on February until June 2016. The research design was a split plot of Randomized Complete Block Design (RCBD) with two factors (plant spacing as main plot, nitrogen fertilizer dosage as sub plot) and three replications. The planting space of $1 \mathrm{~m} \times 1 \mathrm{~m}$ showed the better result in growth percentage, number of green leaves, number of cormels per plant, and fresh weight of cormels per plant. The nitrogen fertilizer 100 of $\mathrm{kg}$ urea $\mathrm{ha}^{-1}$ showed the better result in number of green leaves, plant height, and diameter stem. There was no sygnificant influence of the interaction between nitrogen fertilizer and planting spac to growth and production of Cocoyam.
\end{abstract}

Keywords : nitrogen fertilizer, plant spacing, split plot, Cocoyam

\section{ABSTRAK}

Talas belitung (Xanthosoma sagittifolium (L.) Schott) memiliki potensi untuk dikembangkan sebagai sumber karbohidrat selain beras. Penelitian ini bertujuan mengetahui dosis pupuk nitrogen dan jarak tanam terbaik untuk budi daya talas belitung. Percobaan dilaksanakan di Kebun Percobaan Cikabayan Dramaga, Bogor pada bulan Februari hingga Juni 2016 menggunakan rancangan split plot RKLT dua faktor (jarak tanam sebagai petak utama dan dosis pupuk nitrogen sebagai anak petak) dengan tiga ulangan. Berdasarkan hasil pengamatan dan analisa data, jarak tanam $1 \mathrm{~m} \times 1 \mathrm{~m}$ menunjukkan hasil lebih baik terhadap peubah daya tumbuh, jumlah daun hijau, jumlah umbi per tanaman, serta bobot basah umbi per tanaman talas belitung. Perlakuan pupuk nitrogen $100 \mathrm{~kg}_{\text {urea }} \mathrm{ha}^{-1}$ menunjukkan hasil lebih baik terhadap peubah jumlah daun hijau, tinggi tanaman serta diameter batang talas belitung. Interaksi perlakuan pupuk nitrogen dan jarak tanam tidak memberikan pengaruh nyata terhadap pertumbuhan dan produksi talas belitung.

Kata kunci : jarak tanam, pupuk nitrogen, split plot, Talas Belitung 


\section{PENDAHULUAN}

Penduduk Indonesia mengonsumsi beras cukup tinggi yaitu $97.23 \mathrm{~kg}$ per kapita per tahun (Kementan, 2014). Tingginya konsumsi beras tidak didukung dengan produksi pangan nasional yang cukup. Faktor penghambat peningkatan produksi pangan diantaranya adalah penyempitan lahan pertanian serta kesuburan tanah rendah. Sumber karbohidrat masyarakat Indonesia tidak bisa hanya bergantung pada tanaman serealia. Indonesia memiliki sumber karbohidrat selain serealia yaitu umbi-umbian yang hanya dikonsumsi $8.67 \mathrm{~kg}$ per kapita per tahun dengan konsumsi talas hanya $0.42 \mathrm{~kg}$ per kapita per tahun. Oleh sebab itu, pemerintah Indonesia mengeluarkan kebijakan tentang ketahanan pangan dan gizi untuk menjawab permasalahan tersebut. Peraturan tersebut tercantum dalam Peraturan Pemerintah nomer 17 tahun 2015 yang berisi tentang diversifikasi pangan maupun penganekaragaman pangan salah satunya pemanfaatan pangan lokal. Budi daya tanaman umbi penghasil karbohidrat perlu dilakukan untuk mendukung diversifikasi maupun penganekaragaman pangan.

Talas belitung (Xanthosoma sagittifolium (L.) Schott) merupakan umbi penghasil karbohidrat yang belum banyak dimanfaatkan sebagai bahan pangan (Indrasti, 2004). Tanaman ini berasal dari Amerika Selatan akan tetapi sudah dikenal masyarakat Indonesia secara turun temurun sebagai pangan lokal (Sandoval dan Rodriguez, 2014). Umbi ini mengandung karbohidrat $17-26 \%$; air $70-77 \%$; protein $1.3-$ $3.7 \%$; lemak 0.2-0.4\%; dan serat $0,6-1,9 \%$ (Manner, 2011). Daun talas belitung dapat digunakan untuk menurunkan kolesterol pada hewan uji tikus (Jackix et al., 2013). Tepung umbi talas belitung dapat diolah menjadi beras tiruan atau dikenal sebagai beras analog serta sebagai bahan mie instan (Arisandy dan Estiah, 2016; Jatmiko dan Estiah, 2014). Umbi talas belitung memiliki kandungan karbohidrat setara dengan kentang; protein, vitamin, mineral lebih tinggi daripada singkong serta sifatnya mudah dicerna (Onyeka, 2014). Talas belitung memiliki karbohidrat yang cukup tinggi serta terdapat senyawa bioaktif Polisakarida Larut Air (PLA) untuk melancarkan pencernaan dan diosgenin (anti kanker) (Jatmiko dan Estiah, 2014). Oleh karena itu, umbi talas belitung direkomendasikan untuk dikonsumsi penderita diabetes, orang tua, anak-anak yang memiliki alergi gluten, anak autis serta penderita penyakit pencernaan.

Budi daya talas belitung secara luas merupakan upaya peningkatan produktivitas dan bentuk dukungan terhadap program diversifikasi serta penganekaragaman pangan nasional. Menurut Jatmiko dan Estiah (2014) produksi talas belitung pada tahun 2013 di enam provinsi Indonesia sekitar 825 ton dengan luas panen 55 Ha. Peningkatan produktivitas talas belitung memerlukan sarana tumbuh yang optimal diantaranya ketersediaan hara, air, intensitas cahaya, serta ruang tumbuh. Penelitian mengenai ketersediaan hara, air serta intensitas cahaya terhadap tanaman talas belitung pada awal masa pertumbuhan telah dilakukan oleh Anggarwulan et al. (2008) serta Latifa dan Anggarwulan (2009). Anggarwulan et al. (2008) menyatakan bahwa naungan dan ketersediaan air mempengaruhi tinggi tanaman dan kandungan klorofil daun talas belitung secara signifikan. Latifa dan Anggarwulan (2009) menyatakan bahwa perlakuan pupuk ZA secara tunggal berpengaruh terhadap kandungan nitrogen jaringan, aktivitas nitrat reduktase, berat basah dan berat kering tanaman, serta rasio pucuk/akar tanaman talas belitung. Akan tetapi penelitian mengenai respon tanaman talas belitung terhadap ruang tumbuh belum banyak dilakukan. Jarak tanam menentukan ruang tumbuh antar tanaman. Pengaturan jarak tanam perlu dilakukan karena mempengaruhi kompetisi penggunaan air, hara, dan cahaya antar tanaman. Unsur hara yang penting untuk pertumbuhan tanaman adalah nitrogen. Menurut Agegnehu et al. (2016) nitrogen merupakan protein esensial untuk pertumbuhan tanaman untuk inisiasi pembentukan daun dan akar. Oleh karena itu perlu dilakukan penelitian mengenai dosis pupuk nitrogen dan jarak tanam terhadap tanaman talas belitung hingga awal masa inisiasi pembentukan umbi untuk mendapatkan teknik budi daya terbaik.

\section{METODE PENELITIAN}

Penelitian ini dilaksanakan di Kebun Percobaan IPB Cikabayan Dramaga, Bogor dengan ketinggian 240 meter di atas permukaan laut (m dpl), jenis tanah Inseptiol, dan rata-rata curah hujan bulanan sebesar $502.98 \mathrm{~mm}$. Pengukuran parameter pasca panen seperti bobot basah dan bobot kering umbi dilaksanakan di Laboratorium Pasca Panen Departemen Agronomi dan Hortikultura, IPB. Pengujian analisis tanah dan analisis tanaman dilaksanakan di Laboratorium Pengujian, Departemen Agronomi dan Hortikultura, IPB. Penelitian ini dilaksanakan sejak bulan Februari 2016 - Juni 2016. Sarana produksi pertanian yang digunakan dalam penelitian ini adalah umbi Talas Belitung, pupuk urea, pupuk SP-36, pupuk $\mathrm{KCl}$, label, timbangan 
analitik, meteran, jangka sorong, oven, dan peralatan budidaya secara umum.

Rancangan percobaan yang digunakan adalah Rancangan Split Plot Kelompok Lengkap Teracak (Split Plot-RKLT) dengan petak utama perlakuan jarak tanam dan anak petak perlakuan dosis pupuk nitrogen. Terdapat dua perlakuan jarak tanam yaitu $1 \mathrm{~m}$ x $1 \mathrm{~m}$ dan $1 \mathrm{~m}$ x $0,5 \mathrm{~m}$ serta dua perlakuan dosis pupuk nitrogen yaitu $100 \mathrm{~kg}$ urea ha ${ }^{-1}$ dan $200 \mathrm{~kg}$ urea ha ${ }^{-1}$ sehingga terdapat empat kombinasi perlakuan. Masing-masing kombinasi perlakuan diulang tiga kali sehingga terdapat 12 satuan percobaan. Satu satuan percobaan terdiri dari tiga guludan dengan ukuran masing-masing guludan $1 \mathrm{~m} \times 5 \mathrm{~m}$. Jarak tanam diberi kode J1 dan $\mathrm{J} 2$ sedangkan dosis pupuk nitrogen diberi kode N1 dan N2.

Percobaan diawali dengan seleksi bibit berdasarkan diameter pangkal batang. Selanjutnya dilakukan penanaman umbi pada lubang tanam berukuran 10-15 cm. Sebelum ditanam, daun dikurangi untuk mengurangi transpirasi serta guludan ditinggikan agar drainase lancar. Pengukuran tinggi batang dan diameter pangkal batang pada 5 tanaman contoh di setiap petak percobaan juga dilakukan saat penanaman. Pemeliharaan tanaman dilakukan selama 5 bulan sejak umbi ditanam. Pemupukan dilakukan sesuai dengan perlakuan yaitu $\mathrm{N} 1$ dengan dosis $100 \mathrm{~kg}$ $\mathrm{ha}^{-1}$ urea, $150 \mathrm{~kg} \mathrm{ha}^{-1} \mathrm{SP}-36$, dan $100 \mathrm{~kg} \mathrm{ha}^{-1} \mathrm{KCl}$ dan N2 dengan dosis $200 \mathrm{~kg} \mathrm{ha}^{-1}$ urea, $150 \mathrm{~kg} \mathrm{ha}^{-1}$ SP-36, dan $100 \mathrm{~kg} \mathrm{ha}{ }^{-1} \mathrm{KCl}$. Pemupukan diaplikasikan dua kali dengan membuat alur di sekitar tanaman kemudian menutupnya dengan tanah. Aplikasi pertama pada 1 minggu setelah tanam (MST) yaitu $1 / 2$ dosis urea, seluruh dosis SP-36, dan 1/2 dosis $\mathrm{KCl}$. Aplikasi kedua pada 2 bulan setelah tanam (BST) yaitu $1 / 2$ dosis urea dan $1 / 2$ dosis $\mathrm{KCl}$. Pengendalian gulma dilakukan setiap minggu selama masa tanam disertai dengan pembumbunan. Selama masa pemeliharaan dilakukan pengamatan daya tumbuh, jumlah daun hijau, jumlah daun kuning, diameter batang yang diukur $5 \mathrm{~cm}$ dari tanah, serta tinggi tanaman.

Analisis hara dalam tanah dilakukan sebelum pemupukan dan sesudah panen untuk mengetahui kadar $\mathrm{N}$ total, $\mathrm{P}_{2} \mathrm{O}_{5}$ tersedia, dan $\mathrm{K}_{2} \mathrm{O}$ tersedia, C-organik, dan $\mathrm{pH}$ dalam tanah, sedangkan analisis tanaman dilakukan setelah panen untuk mengetahui kandungan hara dalam jaringan tanaman. Sampel analisis tanah sebelum pemupukan hanya satu buah karena dianggap belum ada pengaruh apapun sedangkan sampel analisis setelah panen sebanyak empat sampel dengan rincian setiap perlakuan satu sampel. Sampel analisis tanah diambil secara komposit yang mewakili setiap guludan dari masing-masing perlakuan. Analisis tanaman dilakukan dengan cara mengambil daun yang tidak terlalu tua maupun tidak terlalu muda kemudian mengoven pada suhu $70{ }^{\circ} \mathrm{C}$ selama 24 jam (Agbede, 2008). Setelah daun kering, kemudian digiling dengan blender hingga halus lalu dibawa ke laboratorium untuk dilakukan pengujian kandungan hara $(\mathrm{N}$ total, $\mathrm{P}_{2} \mathrm{O}_{5}$ tersedia, dan $\mathrm{K}_{2} \mathrm{O}$ tersedia) pada daun (Munson, 1998). Pengujian analisis tanah maupun tanaman dilakukan di Laboratorium Pengujian Departemen Agronomi dan Hortikultura, Fakultas Pertanian, IPB

Panen dilakukan pada umur 20 MST terhadap 5 tanaman contoh di setiap petak perlakuan. Parameter yang diamati antara lain bobot basah umbi dan brangkasan tiap tanaman, diameter pangkal batang, jumlah umbi per tanaman, serta rata-rata diameter dan panjang umbi per tanaman. Selanjutnya umbi dan brangkasan dioven dengan suhu $80{ }^{\circ} \mathrm{C}$ selama $2 \mathrm{x}$ 24 jam untuk mengetahui bobot keringnya. Semua data yang terkumpul kemudian dilakukan analisis data menggunakan analisis sidik ragam (Uji F) pada taraf 5\%. Jika hasil Uji F berpengaruh nyata, akan dilakukan uji lanjut menggunakan Uji Selang Berganda Duncan (DMRT) dengan taraf 5\%. Software yang digunakan adalah SAS 9.1.3 serta Microsoft Excel.

\section{HASIL DAN PEMBAHASAN}

\section{Kondisi Umum}

Jenis tanah pada pertanaman talas belitung adalah Inseptisol yang termasuk golongan tanah mineral masam. Menurut Barchia (2009) jenis tanah ini memiliki beberapa permasalahan di antaranya $\mathrm{pH}$ masam dan kandungan bahan organik rendah (biasanya hanya sekitar 0.5-5\%). Bahan organik mempengaruhi sifat fisik dan kimia tanah serta mempengaruhi pertumbuhan tanaman. Berdasarkan hasil analisis tanah, nilai C-organik tanah pada pertanaman talas belitung di Kebun Percobaan Cikabayan sebelum pemupukan dan setelah panen termasuk kriteria rendah. Rendahnya nilai bahan organik tanah mengurangi kemampuan tanah menahan air dan unsur hara. Menurut Hardjowigeno (2003) bahan organik berfungsi sebagai sumber hara makro maupun mikro serta sumber energi bagi mikroorganisme. Derajat keasaman $(\mathrm{pH})$ pada pertanaman talas belitung sebelum pemupukan dan setelah panen termasuk kriteria masam. Sebagian besar unsur hara tidak tersedia pada $\mathrm{pH}$ masam karena tidak adanya aktivitas organisme pengikat hara atau unsur tersebut terikat dengan unsur lain seperti Al. Menurut Munawar (2011) 
tanah yang memiliki $\mathrm{pH}$ rendah (masam) dapat disebabkan oleh curah hujan berlebihan (terlalu banyak ion $\mathrm{H}^{+}$) serta pemupukan yang mengandung unsur ammonium dan kalsium monofosfat sebagai sumber kemasaman tanah.

Persentase $\mathrm{N}$ total dalam tanah sebelum pemupukan termasuk kriteria sedang dan setelah panen termasuk kriteria rendah hingga sedang. Hal ini diduga pupuk nitrogen yang diaplikasikan mengalami leaching karena air hujan serta terbawa saat panen. Menurut Wijaya (2008) rendahnya persentase $\mathrm{N}$ total dalam tanah diduga dipengaruhi oleh rendahnya kandungan bahan organik serta $\mathrm{pH}$ masam. Nilai $\mathrm{P}_{2} \mathrm{O}_{5}$ tersedia sebelum pemupukan termasuk kriteria sangat rendah namun setelah panen menjadi beragam dari kriteria tinggi, sangat tinggi, dan rendah. Nilai $\mathrm{P}_{2} \mathrm{O}_{5}$ tersedia yang rendah (sebelum pemupukan) dapat diduga karena $\mathrm{pH}$ masam dan kandungan bahan organik rendah ( $\mathrm{P}$ terikat $\mathrm{Al}$ dan $\mathrm{Fe})$ sedangkan setelah panen nilai $\mathrm{P}_{2} \mathrm{O}_{5}$ tersedia meningkat tajam diduga karena penambahan pupuk SP-36. Tingginya nilai $\mathrm{P}_{2} \mathrm{O}_{5}$ tersedia juga diduga unsur tersebut lambat bereaksi di dalam tanah serta tidak mudah hilang. Menurut Munawar (2011) tanaman hanya menyerap unsur $\mathrm{P}$ maksimal $20 \%$ dari pupuk yang diberikan dan sisanya akan tertinggal di perakaran atau tersedia bagi tanaman musim berikutnya. Nilai $\mathrm{K}_{2} \mathrm{O}$ tersedia sebelum pemupukan dan setelah panen termasuk kriteria sangat rendah. Rendahnya nilai $\mathrm{K}_{2} \mathrm{O}$ dapat disebabkan oleh pencucian air hujan, tanah tererosi, $\mathrm{pH}$ masam serta rendahnya nilai KTK. Menurut Munawar (2011) kondisi tanah dengan $\mathrm{pH}$ masam akan menyebabkan unsur $\mathrm{K}$ tidak tersedia karena tanah dipenuhi ion $\mathrm{Al}^{3+}$ sedangkan nilai KTK tanah yang rendah akan menyebabkan unsur $\mathrm{K}$ lebih mudah larut.

$$
\text { Kapasitas Tukar Kation (KTK) }
$$

merupakan kemampuan tanah menjerap kation. Semakin tinggi nilai KTK, maka kemampuan tanah menjerap kation semakin tinggi sehingga hara tersedia dalam tanah. Berdasarkan analisis tanah dapat diketahui nilai KTK termasuk kriteria rendah hingga sedang. Hal ini menunjukkan bahwa ketersediaan hara dalam tanah antara rendah hingga sedang mengikuti nilai KTK. Menurut Hardjowigeno (2003) tanah dengan bahan organik rendah atau tanah berpasir memiliki nilai KTK rendah. Analisis tanaman dilakukan sebagai pelengkap informasi ketersediaan hara dan rekomendasi pemupukan. Jaringan tanaman yang paling sering diambil adalah daun akan tetapi dapat berbeda antar tanaman. Konsentrasi hara N, P, dan K pada daun tanaman talas belitung termasuk kriteria normal. Hal ini menunjukkan bahwa unsur hara pada jaringan tanaman cukup tersedia walaupun berdasarkan analisis hara dalam tanah terdapat beberapa unsur hara yang nilainya rendah atau sangat rendah setelah panen. Unsur hara yang nilainya rendah atau sangat rendah dalam tanah disebabkan karena unsur tersebut sulit tersedia untuk tanaman, terikat dengan koloid tanah, atau terbawa saat panen.

Jenis OPT yang ditemukan pada pertanaman talas belitung antara lain serangga, cendawan, dan gulma. Serangga yang ditemukan antara lain kepik dan kutu daun sedangkan gulma yang ditemukan antara lain Borreria alata, Mimosa pudica, Axonopus compressus, dan Emilia sonchifolia. Menurut Gardner et al. (1991) gulma berkompetisi dengan tanaman dalam memperebutkan faktor lingkungan untuk pertumbuhan antara lain cahaya, air, dan hara. Berdasarkan pengamatan di lapangan, serangan penyakit Cocoyam Root Rot Disease (CRRD) tidak ditemukan akan tetapi setelah dilakukan identifikasi penyakit di Klinik Tanaman, Departemen Proteksi Tanaman, Fakultas Pertanian, IPB ditemukan cendawan Colletotrichum sp. pada daun kuning yang basah dan lembab. Cendawan ini berbentuk bulan sabit dengan lingkaran di tengahnya. Cendawan Colletotrichum sp. merupakan penyebab penyakit antraknosa dengan pola serangan konsentris. Penyakit CRRD tidak ditemukan pada pertanaman Talas Belitung karena umbi tanaman tidak menunjukkan kondisi busuk. Pengendalian OPT ini dilakukan melalui penyemprotan insektisida dan fungisida sebanyak dua kali. Bahan aktif yang digunakan adalah Mankozeb $80 \%$ (fungisida) dan Karbari 85\% (insektisida) dengan konsentrasi $2 \mathrm{~g}$ $1^{-1}$. Pengendalian manual juga dilakukan dengan cara memotong bagian tanaman yang sakit.

\section{Pertumbuhan Talas Belitung}

Berdasarkan rekapitulasi sidik ragam, dapat diketahui bahwa jarak tanam hanya berpengaruh nyata terhadap daya tumbuh talas belitung pada umur 20 MST. Perlakuan pupuk nitrogen secara tunggal dan interaksi antara jarak tanam dengan pupuk nitrogen tidak berpengaruh nyata terhadap daya tumbuh talas belitung pada semua umur tanaman. Jarak tanam berpengaruh nyata terhadap jumlah daun hijau talas belitung pada 10 MST, 11 MST, 12 MST, 14 MST, 17 MST, dan 18 MST serta konsisten berpengaruh sangat nyata pada umur tanaman 19 MST hingga 20 MST. Perlakuan pupuk nitrogen berpengaruh sangat nyata terhadap jumlah daun hijau talas belitung pada 4 MST dan 5 MST serta berpengaruh nyata pada 10 MST dan 17 MST. 
Interaksi perlakuan jarak tanam dan pupuk nitrogen berpengaruh nyata terhadap jumlah daun hijau talas belitung hanya pada 4 MST. Pengamatan jumlah daun kuning tanaman talas belitung baru dimulai pada 7 MST. Jarak tanam berpengaruh nyata terhadap jumlah daun kuning talas belitung hanya pada 10 MST dan 11 MST. Perlakuan pupuk nitrogen berpengaruh nyata terhadap jumlah daun kuning talas belitung pada 8 MST dan 12 MST serta berpengaruh sangat nyata pada 11 MST. Interaksi antara perlakuan jarak tanam dan pupuk nitrogen tidak berpengaruh nyata terhadap jumlah daun kuning talas belitung pada semua umur tanaman.

Jarak tanam tidak berpengaruh nyata terhadap tinggi tanaman talas belitung pada semua umur. Perlakuan pupuk nitrogen berpengaruh nyata terhadap tinggi tanaman talas belitung pada umur tanaman 8 MST, 9 MST, dan 11 MST sampai 14 MST serta berpengaruh sangat nyata pada umur 10 MST serta 15-16 MST. Interaksi jarak tanam dan pupuk nitrogen hanya berpengaruh nyata terhadap tinggi tanaman talas belitung pada 16 MST. Jarak tanam tidak berpengaruh nyata terhadap diameter batang talas belitung pada semua umur tanaman. Perlakuan pupuk nitrogen hanya berpengaruh nyata terhadap diameter batang talas belitung pada 5 MST-8 MST, $11 \mathrm{MST}$, dan $12 \mathrm{MST}$. Interaksi antara jarak dan pupuk nitrogen tidak berpengaruh nyata terhadap diameter batang talas belitung pada semua umur tanaman.

Daya Tumbuh. Daya tumbuh talas belitung hanya berbeda nyata oleh pengaruh jarak tanam setelah 20 MST. Hal ini diduga karena tanaman tidak membutuhkan ruang tumbuh yang luas pada masa awal pertumbuhan sehingga pengaruh jarak tanam tidak nyata sebelum 20 MST. Hal ini sesuai dengan penelitian Nurshanti (2008) yang menyatakan bahwa variasi jarak tanam tidak berbeda nyata terhadap daya tumbuh bibit tanaman buru hotong pada awal masa tumbuhnya. Tabel 1 menunjukkan daya tumbuh talas belitung pada jarak tanam $1 \mathrm{~m} \mathrm{x} 1 \mathrm{~m}$ lebih tinggi $3,84 \%$ daripada jarak tanam $1 \mathrm{~m} \times 0,5 \mathrm{~m}$. Hal ini diduga karena jarak tanam yang lebih lebar $(1 \mathrm{~m} \times 1 \mathrm{~m})$ memiliki persaingan penggunaan hara, air, dan cahaya lebih rendah daripada jarak tanam yang lebih sempit $(1 \mathrm{~m} \times 0,5 \mathrm{~m})$ sehingga daya tumbuhnya lebih baik. Hal ini sesuai dengan penelitian Budiastuti (2000) yang menyatakan bahwa jarak tanam yang lebih renggang akan menghasilkan pertumbuhan lebih baik bagi tanaman kacang hijau daripada jarak tanam yang lebih rapat. Perlakuan pupuk nitrogen tidak berpengaruh nyata terhadap daya tumbuh talas belitung pada semua umur tanaman. Hal ini diduga karena pupuk nitrogen mengalami leaching setelah aplikasi pemupukan. Berdasarkan Data BMKG dari Stasiun Klimatologi Klas 1 Dramaga, curah hujan pada saat aplikasi pupuk yaitu bulan Februari $2016(610 \mathrm{~mm})$ dan April $2016(558,2 \mathrm{~mm})$ tergolong tinggi sehingga diduga nitrogen tercuci oleh air hujan. Menurut Wijaya (2008) pupuk nitrogen mudah hilang karena leaching (terbawa air hujan atau irigasi), run off (terbawa aliran permukaan), erosi karena areal miring serta emisi (menguap menjadi $\mathrm{NH}_{3}$ ). Interaksi antara jarak tanam dengan pupuk nitrogen tidak berpengaruh nyata terhadap daya tumbuh talas belitung hingga umur tanaman 20 MST. Hal ini diduga karena faktor anak petak yaitu pupuk nitrogen tidak berpengaruh nyata terhadap daya tumbuh sehingga tidak terjadi interaksi antara kedua faktor (jarak tanam dan pupuk nitrogen).

Tabel 1. Pengaruh jarak tanam dan pupuk nitrogen terhadap daya tumbuh talas belitung pada 20 MST

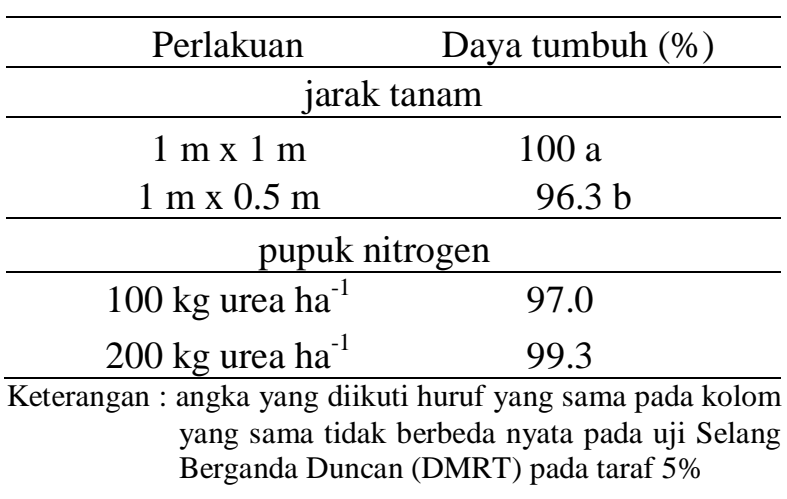

Jumlah Daun Hijau. Jumlah daun hijau talas belitung dipengaruhi secara nyata oleh jarak tanam pada umur 10-12 MST, 14 MST, serta 1720 MST. Tanaman dengan perlakuan jarak tanam $1 \mathrm{~m} \times 1 \mathrm{~m}$ menghasilkan jumlah daun hijau $72.72 \%$ lebih banyak daripada jarak tanam $1 \mathrm{~m} \mathrm{x}$ $0.5 \mathrm{~m}$ pada umur $10 \mathrm{MST}$ (Tabel 2). Hal ini diduga karena rendahnya kompetisi penguasaan sarana tumbuh antar tanaman. Menurut Budiastuti (2000) perlakuan jarak tanam akan mempengaruhi jumlah cabang tanaman kacang hijau yang juga mempengaruhi jumlah daun. Jarak tanam renggang akan memberikan jumlah daun lebih baik daripada jarak tanam yang lebih rapat. Menurut Ahmed et al. (2016) jarak tanam yang lebih renggang akan menyebabkan pertumbuhan vegetatif lebih tinggi per unit area. Menurut Gardner et al. (2008) jarak tanam renggang akan menyebabkan tidak adanya kompetisi antar dan dalam tanaman itu sendiri pada awal masa pertumbuhan. 
Tanaman talas belitung dengan perlakuan pupuk nitrogen $100 \mathrm{~kg}$ urea ha ${ }^{-1}$ menghasilkan jumlah daun hijau $23.35 \%$ lebih banyak daripada perlakuan $200 \mathrm{~kg}$ urea ha ${ }^{-1}$ pada umur $4 \mathrm{MST}$ akan tetapi pada umur 17 MST jumlah daun hijau pada perlakuan $200 \mathrm{~kg}$ urea $\mathrm{ha}^{-1}$ lebih banyak $12.93 \%$ daripada perlakuan $100 \mathrm{~kg}$ urea $\mathrm{ha}^{-1}$ (Tabel 2). Hal ini diduga karena adanya aplikasi pupuk nitrogen kedua pada 8 MST yang menambah ketersediaan hara dalam tanah. Menurut Gardner et al. (2008) penambahan pupuk nitrogen diharapkan menambah jumlah daun karena nitrogen menambah kofaktor enzim untuk pembentukan karbohidrat. Selain itu, diduga kebutuhan nitrogen tanaman semakin bertambah dengan bertambahnya umur tanaman karena tanaman membutuhkan suplai fotosintat untuk pembentukan umbi. Oleh karena itu, dapat diketahui bahwa perlakuan pupuk nitrogen $200 \mathrm{~kg}$ urea $\mathrm{ha}^{-1}$ secara tunggal akan membentuk daun hijau lebih banyak seiring bertambahnya umur tanaman namun secara tidak nyata sehingga 100 $\mathrm{kg}$ urea ha ${ }^{-1}$ pun sudah cukup untuk pembentukan daun hijau talas belitung hingga umur tanaman 20 MST.

Tabel 2. Pengaruh jarak tanam dan pupuk nitrogen terhadap jumlah daun hijau talas belitung

\begin{tabular}{|c|c|c|c|c|}
\hline \multirow{2}{*}{ Umur } & \multicolumn{2}{|c|}{ Jarak tanam } & \multicolumn{2}{|c|}{ Pupuk nitrogen } \\
\hline & $1 \mathrm{mx} 1 \mathrm{~m}$ & $1 \mathrm{~m} \times 0,5 \mathrm{~m}$ & $100 \mathrm{~kg}$ urea ha ${ }^{-1}$ & $200 \mathrm{~kg}$ urea ha ${ }^{-1}$ \\
\hline & & & ii. & \\
\hline $4 \mathrm{MST}$ & 2.7 & 2.37 & $2.80 \mathrm{a}$ & $2.27 \mathrm{~b}$ \\
\hline $5 \mathrm{MST}$ & 2.9 & 2.53 & $3.00 \mathrm{a}$ & $2.43 \mathrm{~b}$ \\
\hline $10 \mathrm{MST}$ & $3.23 \mathrm{a}$ & $1.87 \mathrm{~b}$ & $2.77 \mathrm{a}$ & $2.33 \mathrm{~b}$ \\
\hline $11 \mathrm{MST}$ & $3.37 \mathrm{a}$ & $2.00 \mathrm{~b}$ & 2.77 & 2.6 \\
\hline $12 \mathrm{MST}$ & $3.67 \mathrm{a}$ & $1.97 \mathrm{~b}$ & 2.97 & 2.67 \\
\hline $14 \mathrm{MST}$ & $2.70 \mathrm{a}$ & $1.37 \mathrm{~b}$ & 1.97 & 2.1 \\
\hline $17 \mathrm{MST}$ & $3.30 \mathrm{a}$ & $2.30 \mathrm{~b}$ & $2.63 \mathrm{~b}$ & $2.97 \mathrm{a}$ \\
\hline $18 \mathrm{MST}$ & $3.23 \mathrm{a}$ & $2.07 \mathrm{~b}$ & 2.57 & 2.73 \\
\hline
\end{tabular}

Keterangan : angka yang diikuti huruf yang sama pada baris yang sama masing-masing perlakuan jarak tanam dan pupuk nitrogen tidak berbeda nyata pada uji Selang Berganda Duncan (DMRT) pada taraf 5\%.

Interaksi antara jarak tanam dan pupuk nitrogen berpengaruh nyata terhadap jumlah daun hijau talas belitung hanya pada 4 MST (Tabel 3). Hal ini disebabkan perlakuan pupuk nitrogen tidak berpengaruh nyata secara konsisten terhadap jumlah daun hijau sehingga tidak adanya pengaruh interaksi antara kedua perlakuan. Perlakuan jarak tanam $1 \mathrm{~m} \times 1 \mathrm{~m}$ dan pupuk nitrogen $100 \mathrm{~kg}$ urea ha ${ }^{-1}$ menunjukkan jumlah daun hijau terbaik sebanyak 2.87 helai akan tetapi tidak berbeda nyata dengan perlakuan jarak tanam $1 \mathrm{~m} \times 0.5 \mathrm{~m}$ dan pupuk nitrogen $100 \mathrm{~kg}$ urea ha ${ }^{-1}$ sebanyak 2.73 helai. Berdasarkan analisis tanah, perlakuan jarak tanam $1 \mathrm{~m}$ x $1 \mathrm{~m}$ dan kombinasi dua perlakuan pupuk nitrogen memiliki nilai KTK lebih baik daripada perlakuan jarak tanam $1 \mathrm{~m} \mathrm{x}$ $0.5 \mathrm{~m}$. Menurut Munawar (2011) semakin tinggi nilai KTK maka kemampuan tanah menjerap hara semakin baik sehingga hara dalam tanah semakin tersedia. Akan tetapi karena interaksi kedua perlakuan hanya nyata pada 4 MST maka dapat diduga bahwa semua kombinasi perlakuan tidak berbeda nyata terhadap jumlah daun hijau talas belitung.
Tabel 3. Interaksi antara jarak tanam dan pupuk nitrogen terhadap jumlah daun hijau talas belitung pada 4 MST

\begin{tabular}{|c|c|c|}
\hline \multirow{2}{*}{ Jarak tanam } & \multicolumn{2}{|c|}{ Pupuk nitrogen } \\
\hline & $100 \mathrm{~kg}$ urea ha ${ }^{-1}$ & $200 \mathrm{~kg}$ urea ha ${ }^{-1}$ \\
\hline & \multicolumn{2}{|c|}{...helai. } \\
\hline $1 \mathrm{mx} 1 \mathrm{~m}$ & $2.87 \mathrm{a}$ & $2.53 \mathrm{~b}$ \\
\hline $1 \mathrm{~m} \times 0.5 \mathrm{~m}$ & $2.73 \mathrm{a}$ & $2.00 \mathrm{c}$ \\
\hline Keterangan : & $\begin{array}{l}\text { yang diikuti hu } \\
\text { berbeda nyata } \\
\text { (DMRT) pad }\end{array}$ & $\begin{array}{l}\text { ang sama pada tabe } \\
\text { iji Selang Bergand } \\
5 \%\end{array}$ \\
\hline
\end{tabular}

Jumlah Daun Kuning. Decoteau (2005) menyatakan bahwa fenomena daun kuning merupakan fenomena kehilangan klorofil yang dipengaruhi faktor lingkungan (panjang hari, radiasi, dan suplai nitrogen) serta faktor hormon dari tanaman tersebut. Menurut Lim et al. (2007) fenomena ini dapat terjadi karena berubahnya kloroplas menjadi karoten dan santofil. Daun kuning juga dapat terbentuk karena adanya penyaluran hara ke bagian lain seperti biji dan daun muda. Banyaknya jumlah daun kuning dapat diduga berimbang dengan pembentukan daun hijau karena adanya transfer hara dari daun kuning ke daun hijau. Akan tetapi, banyaknya jumlah daun kuning talas belitung tidak diharapkan karena akan mengurangi suplai fotosintat untuk pertumbuhan dan produksi umbi. 
Tabel 4 menunjukkan tanaman talas belitung dengan jarak tanam $1 \mathrm{~m} \times 0.5 \mathrm{~m}$ menghasilkan jumlah daun kuning $32.86 \%$ lebih banyak daripada jarak tanam $1 \mathrm{~m} \times 1 \mathrm{~m}$ pada umur 10 MST. Daun kuning yang ditemukan pada pertanaman talas belitung bukan hanya fenomena umum karena adanya transfer hara ke daun hijau akan tetapi juga ditemukan karena adanya serangan cendawan Colletotrichum sp. Hal ini diduga karena jarak tanam yang lebih rapat akan menyebabkan kelembaban tinggi sehingga hama penyakit lebih cepat menular antar tanaman. Selain itu, salah satu cara penyebaran cendawan Colletotrichum sp. melalui kontak dengan tanaman yang sakit. Jarak tanam yang lebih rapat memungkinkan kontak lebih tinggi dengan tanaman yang sakit. Menurut Wiyono dan Manuwoto (2008) penyebaran cendawan Colletotrichum sp. yang menyebabkan penyakit antraknosa pada pepaya dipengaruhi oleh kelembaban lingkungan. Oleh karena itu, dapat diketahui bahwa perlakuan dengan jarak tanam 1 m x $1 \mathrm{~m}$ lebih baik karena menghasikan jumlah daun kuning lebih sedikit daripada jarak tanam 1 $\mathrm{m} \times 0.5 \mathrm{~m}$.

Tanaman dengan perlakuan pupuk nitrogen $100 \mathrm{~kg}$ urea $\mathrm{ha}^{-1}$ menghasilkan jumlah daun kuning $90.91 \%$ lebih banyak daripada perlakuan $200 \mathrm{~kg}$ urea ha ${ }^{-1}$ pada $11 \mathrm{MST}$, akan tetapi pada 12 MST perlakuan pupuk nitrogen 200 $\mathrm{kg}$ urea $\mathrm{ha}^{-1}$ menghasilkan jumlah daun kuning $60.61 \%$ lebih banyak daripada perlakuan $100 \mathrm{~kg}$ urea ha ${ }^{-1}$ (Tabel 4). Hal ini diduga karena nitrogen yang terlalu tinggi akan menyebabkan tanaman mudah terserang penyakit. Menurut Hardjowigeno (2003) kelebihan unsur nitrogen akan menyebabkan tanaman mudah terserang penyakit, batang lemah, dan mudah roboh. Beberapa daun kuning yang ditemukan pada pertanaman talas belitung disebabkan adanya serangan cendawan Colletotrichum sp. Oleh karena itu, dapat diketahui bahwa perlakuan pupuk nitrogen $100 \mathrm{~kg}$ urea $\mathrm{ha}^{-1}$ lebih baik untuk pertumbuhan talas belitung karena menghasilkan daun kuning lebih sedikit daripada perlakuan pupuk nitrogen $200 \mathrm{~kg}$ urea ha $^{-1}$ hingga 20 MST.

Tabel 4. Pengaruh jarak tanam dan pupuk nitrogen terhadap jumlah daun kuning talas belitung

\begin{tabular}{|c|c|c|c|c|}
\hline \multirow{2}{*}{ Umur } & \multicolumn{2}{|c|}{ Jarak tanam } & \multicolumn{2}{|c|}{ Pupuk nitrogen } \\
\hline & $1 \mathrm{~m} \times 1 \mathrm{~m}$ & $1 \mathrm{~m} \times 0.5 \mathrm{~m}$ & $100 \mathrm{~kg}$ urea ha ${ }^{-1}$ & $200 \mathrm{~kg}$ urea ha ${ }^{-1}$ \\
\hline & & & ........helai......... & \\
\hline $8 \mathrm{MST}$ & 0.47 & 0.47 & $0.70 \mathrm{a}$ & $0.23 \mathrm{~b}$ \\
\hline $10 \mathrm{MST}$ & $0.70 \mathrm{~b}$ & $0.93 \mathrm{a}$ & 0.83 & 0.8 \\
\hline $11 \mathrm{MST}$ & $0.40 \mathrm{~b}$ & $0.57 \mathrm{a}$ & $0.63 \mathrm{a}$ & $0.33 \mathrm{~b}$ \\
\hline $12 \mathrm{MST}$ & 0.43 & 0.43 & $0.33 \mathrm{~b}$ & $0.53 \mathrm{a}$ \\
\hline
\end{tabular}

Keterangan : angka yang diikuti huruf yang sama pada baris yang sama masing-masing perlakuan jarak tanam dan pupuk nitrogen tidak berbeda nyata pada uji Selang Berganda Duncan (DMRT) pada taraf 5\%

Interaksi antara perlakuan jarak tanam dan pupuk nitrogen tidak berpengaruh nyata terhadap jumlah daun kuning talas belitung pada semua umur tanaman. Hal ini diduga karena kedua perlakuan tidak berpengaruh nyata secara bersamaan pada satu waktu misalnya pada umur tanaman 8 MST dan 12 MST hanya perlakuan pupuk nitrogen yang berpengaruh nyata terhadap jumlah daun kuning talas belitung. Oleh karena itu dapat diketahui bahwa kedua perlakuan tidak berpengaruh terhadap pembentukan daun kuning secara bersamaan akan tetapi pengaruhnya tampak secara tunggal.

Tinggi Tanaman. Perlakuan jarak tanam tidak mempengaruhi tinggi tanaman talas belitung pada semua umur tanaman. Hal ini diduga karena tidak ada persaingan penggunaan cahaya matahari antar tanaman. Penelitian Fitria (2007) menyatakan bahwa jarak tanam tidak berpengaruh nyata terhadap tinggi tanaman buru hotong (Setaria italica (L.) Beauv) karena tidak ada persaingan penggunaan cahaya. Penelitian Welde dan Grebemariam (2016) juga menyatakan bahwa jarak tanam tidak berpengaruh nyata terhadap tinggi tanaman jagung. Berdasarkan pengamatan di lapangan, tanaman talas belitung tumbuh lambat dan kerdil karena serangan hama dan penyakit sampai umur 12 MST sehingga menyebabkan persaingan penggunaan cahaya rendah. Tanaman talas belitung pada perlakuan pupuk nitrogen $100 \mathrm{~kg}$ urea ha ${ }^{-1}$ menunjukkan tinggi tanaman secara konsisten lebih baik daripada perlakuan pupuk nitrogen $200 \mathrm{~kg}$ urea ha $^{-1}$ pada 8 MST hingga 16 MST (Tabel 5). Perlakuan pupuk nitrogen $100 \mathrm{~kg}$ urea ha ${ }^{-1}$ menghasilkan tinggi tanaman $39.27 \%$ lebih baik daripada pupuk nitrogen $200 \mathrm{~kg}$ urea ha ${ }^{-1}$ pada 8 MST. Hal ini diduga karena nitrogen yang berlebihan tidak akan dimanfaatkan oleh tanaman. Menurut Pratama (2010) pemberian pupuk nitrogen dengan dosis yang sesuai akan meningkatkan nitrogen pada rhizofer tanah akan tetapi jika berlebihan justru bersifat toksik 
terhadap tanaman. Penelitian Adil et al. (2006) menyatakan bahwa perlakuan urea $5 \mathrm{~g}$ per pot menyebabkan tomat dan okra tidak tumbuh karena urea dengan dosis terlalu tinggi melepaskan nitrogen terlalu tinggi ke tanah serta akan meracuni tanaman. Oleh sebab itu, perlakuan pupuk nitrogen $100 \mathrm{~kg}$ urea ha ${ }^{-1}$ menghasilkan tinggi tanaman talas belitung lebih baik daripada $200 \mathrm{~kg}$ urea ha ${ }^{-1}$ hingga 20 MST.

Tabel 5. Pengaruh pupuk nitrogen terhadap tinggi tanaman talas belitung

\begin{tabular}{|c|c|c|}
\hline \multirow{2}{*}{ Umur } & \multicolumn{2}{|c|}{ Pupuk nitrogen } \\
\hline & $100 \mathrm{~kg}$ urea ha ${ }^{-1}$ & $200 \mathrm{~kg}$ urea ha ${ }^{-1}$ \\
\hline $8 \mathrm{MST}$ & $32.98 \mathrm{a}$ & $23.68 \mathrm{~b}$ \\
\hline 9 MST & $34.73 \mathrm{a}$ & $24.43 \mathrm{~b}$ \\
\hline $10 \mathrm{MST}$ & $35.08 \mathrm{a}$ & $21.95 \mathrm{~b}$ \\
\hline $11 \mathrm{MST}$ & $35.60 \mathrm{a}$ & $24.25 \mathrm{~b}$ \\
\hline $12 \mathrm{MST}$ & $37.37 \mathrm{a}$ & $27.63 \mathrm{~b}$ \\
\hline $13 \mathrm{MST}$ & $36.42 \mathrm{a}$ & $27.27 \mathrm{~b}$ \\
\hline $14 \mathrm{MST}$ & $34.65 \mathrm{a}$ & $27.12 \mathrm{~b}$ \\
\hline $15 \mathrm{MST}$ & $34.87 \mathrm{a}$ & $26.42 \mathrm{~b}$ \\
\hline $16 \mathrm{MST}$ & $34.48 \mathrm{a}$ & $28.72 \mathrm{~b}$ \\
\hline Keterang & $\begin{array}{l}\text { yang diikuti hy } \\
\text { ama tidak berb } \\
\text { nda Duncan (DI }\end{array}$ & $\begin{array}{l}\text { g sama pada ba } \\
\text { ata pada uji Selc } \\
\text { ada taraf } 5 \%\end{array}$ \\
\hline
\end{tabular}

Interaksi jarak tanam dan pupuk nitrogen hanya berpengaruh nyata pada umur tanaman 16 MST (Tabel 6). Hal ini diduga karena hanya perlakuan pupuk nitrogen yang berpengaruh nyata terhadap tinggi tanaman talas belitung sehingga tidak muncul interaksi antara jarak tanam dan pupuk nitrogen. Interaksi jarak tanam dan pupuk nitrogen terbaik adalah perlakuan jarak tanam $1 \mathrm{~m}$ x $1 \mathrm{~m}$ dan pupuk nitrogen $100 \mathrm{~kg}$ urea ha ${ }^{-1}$ dengan tinggi tanaman $44.5 \mathrm{~cm}$ serta berbeda nyata dengan tiga perlakuan lainnya. Hal ini diduga karena nilai KTK perlakuan tersebut (18.79 me $100 \mathrm{~g}^{-1}$ tanah) paling tinggi dibandingkan tiga perlakuan lainnya. Menurut Munawar (2011) semakin tinggi nilai KTK maka hara semakin tersedia di dalam tanah. Oleh karena itu dapat diduga bahwa perlakuan jarak tanam dan pupuk nitrogen lebih tampak pengaruhnya apabila diaplikasikan secara tunggal daripada bersamasama.

Tabel 6. Interaksi antara jarak tanam dan pupuk nitrogen terhadap tinggi tanaman talas belitung pada 16 MST.

\begin{tabular}{|c|c|c|}
\hline \multirow{2}{*}{ Jarak tanam } & \multicolumn{2}{|c|}{ Pupuk nitrogen } \\
\hline & $100 \mathrm{~kg}$ urea ha ${ }^{-1}$ & $200 \mathrm{~kg}$ urea ha ${ }^{-1}$ \\
\hline & \multicolumn{2}{|c|}{ $\ldots \ldots \ldots \ldots \ldots \ldots \ldots \ldots, \mathrm{cm} . \ldots \ldots \ldots \ldots \ldots \ldots \ldots$} \\
\hline $1 \mathrm{~m} \times 1 \mathrm{~m}$ & $44,50 \mathrm{a}$ & $35,57 \mathrm{~b}$ \\
\hline $1 \mathrm{~m} \times 0,5 \mathrm{~m}$ & $24,47 \mathrm{c}$ & $21,87 \mathrm{c}$ \\
\hline Keterangan : a & $\begin{array}{l}\text { a yang diikuti hur } \\
\text { berbeda nyata } \\
\text { an (DMRT) pada }\end{array}$ & $\begin{array}{l}\text { ang sama pada tal } \\
\text { ji Selang Bergan } \\
5 \%\end{array}$ \\
\hline
\end{tabular}

Diameter batang. Diameter batang talas belitung tidak dipengaruhi oleh jarak tanam pada semua umur tanaman. Hal ini diduga karena tidak adanya persaingan penggunaan hara, air, dan cahaya antar tanaman. Berdasarkan pengamatan di lapangan ditemukan banyak tanaman yang kerdil dan terserang penyakit. Tanaman dengan perlakuan pupuk nitrogen $100 \mathrm{~kg}$ urea $\mathrm{ha}^{-1}$ menghasilkan diameter batang talas belitung lebih baik $31.32 \%$ daripada perlakuan pupuk nitrogen $200 \mathrm{~kg}$ urea ha $^{-1}$ pada 5 MST (Tabel 7). Hal ini diduga karena nitrogen yang berlebih tidak akan dimanfaatkan oleh tanaman. Menurut Pratama (2010) jumlah nitrogen yang diserap oleh tanaman cenderung sesuai dengan pertumbuhannya serta dipengaruhi oleh nilai KTK tanah sehingga kelebihan unsur nitrogen tidak akan dimanfaatkan oleh tanaman. Rendahnya nilai KTK pada pertanaman talas belitung dapat diketahui sebanding dengan penyerapan hara oleh tanaman. Oleh karena itu, dapat diketahui bahwa perlakuan pupuk nitrogen $100 \mathrm{~kg}$ urea $\mathrm{ha}^{-1}$ menunjukkan hasil lebih baik daripada $200 \mathrm{~kg}$ urea $\mathrm{ha}^{-1}$ terhadap diameter batang talas belitung hingga 20 MST.

Interaksi antara jarak tanam dan pupuk nitrogen tidak berpengaruh nyata terhadap peubah diameter batang talas belitung pada semua umur tanaman. Hal ini diduga karena hanya perlakuan pupuk nitrogen yang berpengaruh nyata terhadap diameter batang talas belitung sehingga tidak muncul interaksi antara jarak tanam dan pupuk nitrogen. Oleh karena itu dapat diduga bahwa perlakuan jarak tanam dan pupuk nitrogen lebih tampak pengaruhnya apabila diaplikasikan secara tunggal daripada bersama-sama.

Tabel 7. Pengaruh pupuk nitrogen terhadap diameter batang talas belitung

\begin{tabular}{|c|c|c|}
\hline \multirow{2}{*}{ Umur } & \multicolumn{2}{|c|}{ Pupuk nitrogen } \\
\hline & $100 \mathrm{~kg}$ urea ha ${ }^{-1}$ & $200 \mathrm{~kg}$ urea ha ${ }^{-1}$ \\
\hline & & $\mathrm{m}$ \\
\hline $5 \mathrm{MST}$ & $2.39 \mathrm{a}$ & $1.82 \mathrm{~b}$ \\
\hline $6 \mathrm{MST}$ & $2.45 \mathrm{a}$ & $1.83 \mathrm{~b}$ \\
\hline $7 \mathrm{MST}$ & $2.66 \mathrm{a}$ & $1.94 \mathrm{~b}$ \\
\hline $8 \mathrm{MST}$ & $2.98 \mathrm{a}$ & $2.22 \mathrm{~b}$ \\
\hline $11 \mathrm{MST}$ & $2.98 \mathrm{a}$ & $2.30 \mathrm{~b}$ \\
\hline $12 \mathrm{MST}$ & $3.04 \mathrm{a}$ & $2.37 \mathrm{~b}$ \\
\hline Keterangan : & $\begin{array}{l}\text { angka yang diikut } \\
\text { baris yang sama tid } \\
\text { Selang Berganda D } \\
5 \%\end{array}$ & $\begin{array}{l}\text { uf yang sama pada } \\
\text { rbeda nyata pada uji } \\
\text { (DMRT) pada taraf }\end{array}$ \\
\hline
\end{tabular}

\section{Produksi Talas Belitung ( sagittifolium (L.) Schott)}

Produksi talas belitung yang diharapkan adalah jumlah umbi per tanaman, diameter umbi per tanaman, bobot basah serta bobot kering umbi per tanaman. Diameter umbi (ukuran minimal 5 
cm) merupakan kriteria umbi ekonomi untuk produsen keripik sedangkan bobot basah dan bobot kering umbi adalah kriteria umbi ekonomi untuk produsen tepung. Menurut Manner (2011) kandungan tepung umbi talas belitung hanya sekitar $17-34.5 \%$ atau dari $10 \mathrm{~kg}$ umbi basah hanya menghasilkan $3 \mathrm{~kg}$ tepung. Berdasarkan Tabel 8 diketahui bahwa jarak tanam berpengaruh nyata terhadap jumlah umbi per tanaman dengan jumlah umbi pada jarak tanam $1 \mathrm{~m} \times 1 \mathrm{~m}$ lebih banyak 2.7 umbi daripada jarak tanam $1 \mathrm{~m} \times 0.5$ $\mathrm{m}$. Bobot basah umbi per tanaman dipengaruhi secara nyata oleh jarak tanam namun bobot kering umbi per tanaman tidak dipengaruhi secara nyata oleh jarak tanam. Bobot basah umbi per tanaman pada jarak tanam $1 \mathrm{~m} \times 1 \mathrm{~m}$ lebih banyak $157.28 \mathrm{~g}$ daripada jarak tanam $1 \mathrm{~m}$ x $0.5 \mathrm{~m}$. Diameter umbi per tanaman tidak dipengaruhi secara nyata oleh jarak tanam. Jarak tanam $1 \mathrm{~m} \times 1 \mathrm{~m}$ lebih baik untuk produksi umbi talas belitung diduga karena rendahnya kompetisi antar tanaman dalam menggunakan hara, air, dan cahaya. Menurut Gardner et al. (2008) peningkatan hasil panen per tanaman dapat disebabkan oleh penurunan kerapatan tanaman. Menurut Budiastuti (2000) jarak tanam yang lebih renggang menyebabkan rendahnya kompetisi penggunaan air, hara, dan cahaya antar tanaman kacang hijau. Oleh karena itu, secara umum dapat diketahui bahwa jarak tanam yang lebih renggang ( $1 \mathrm{~m} \times 1 \mathrm{~m})$ lebih baik untuk produksi umbi talas belitung.

Pemberian pupuk nitrogen $100 \mathrm{~kg}$ urea $\mathrm{ha}^{-1}$ dan $200 \mathrm{~kg}$ urea ha $\mathrm{h}^{-1}$ tidak berpengaruh nyata terhadap semua peubah produksi talas belitung. Hal ini diduga karena nitrogen merupakan unsur penyusun klorofil yang biasanya dibutuhkan oleh sayuran hijau serta lebih dibutuhkan untuk perkembangan vegetatif tanaman daripada pembentukan umbi. Menurut Hardjowigeno (2003) pemupukan kalium diperlukan dalam pembentukan karbohidrat pada umbi. Menurut Munawar (2011) unsur kalium lebih berperan dalam transportasi asimilat hasil fotosintesis ke jaringan tanaman termasuk ke umbi penyimpan karbohidrat. Selain itu dapat diduga pemberian pupuk nitrogen pada 1 MST dan 8 MST belum dibutuhkan oleh tanaman. Menurut Lebot (2009) tanaman talas belitung responsif pemupukan dan air pada saat fase pembentukan umbi dan tajuk (18-20 MST).

Tabel 8. Pengaruh jarak tanam dan pupuk nitrogen terhadap peubah panen talas belitung pada 20 MST

\begin{tabular}{|c|c|c|c|c|c|}
\hline \multirow[b]{2}{*}{ Perlakuan } & \multicolumn{5}{|l|}{ Peubah } \\
\hline & $\begin{array}{l}\text { Jumlah umbi } \\
\text { per tanaman } \\
\text { (umbi) }\end{array}$ & $\begin{array}{l}\text { Panjang umbi } \\
\text { per tanaman } \\
(\mathrm{cm})\end{array}$ & $\begin{array}{l}\text { Diameter umbi } \\
\text { per tanaman } \\
(\mathrm{cm})\end{array}$ & $\begin{array}{l}\text { BB umbi } \\
\text { per tanaman } \\
(\mathrm{g})\end{array}$ & $\begin{array}{l}\text { BK umbi per } \\
\text { tanaman } \\
(\mathrm{g})\end{array}$ \\
\hline & & & Jarak tanam & & \\
\hline $1 \mathrm{~m} \times 1 \mathrm{~m}$ & $7.17 \mathrm{a}$ & $6.82 \mathrm{~b}$ & 2.05 & $217.54 \mathrm{a}$ & 56.79 \\
\hline \multirow[t]{2}{*}{$1 \mathrm{~m} \times 0.5 \mathrm{~m}$} & $4.47 \mathrm{~b}$ & $8.60 \mathrm{a}$ & 1.64 & $60.26 \mathrm{~b}$ & 13.11 \\
\hline & & & \multicolumn{3}{|l|}{ Pupuk nitrogen } \\
\hline $100 \mathrm{~kg}$ urea ha ${ }^{-1}$ & 5.54 & 7.85 & 1.71 & 133.3 & 30.04 \\
\hline $200 \mathrm{~kg}$ urea ha $^{-1}$ & 6.10 & 7.58 & 1.98 & 144.5 & 39.86 \\
\hline \multirow[b]{2}{*}{ Perlakuan } & \multicolumn{5}{|l|}{ Peubah } \\
\hline & $\begin{array}{l}\text { Diameter } \\
\text { bonggol }(\mathrm{cm})\end{array}$ & $\begin{array}{l}\text { Panjang } \\
\text { bonggol }(\mathrm{cm})\end{array}$ & $\begin{array}{l}\text { BB brangkasan } \\
\text { total } \\
\text { per tanaman } \\
\text { (g) }\end{array}$ & $\begin{array}{l}\text { BK } \\
\text { brangkasan } \\
\text { total } \\
\text { per tanaman } \\
\text { (g) }\end{array}$ & $\begin{array}{l}\text { Indeks Panen } \\
\text { per tanaman }\end{array}$ \\
\hline & & & Jarak tanam & & \\
\hline & 4.29 & 2.81 & 381.1 & 43.79 & 31.04 \\
\hline \multirow[t]{2}{*}{$1 \mathrm{~m} \times 0.5 \mathrm{~m}$} & 2.97 & 2.45 & 69.9 & 11.42 & 24.54 \\
\hline & & & Pupuk nitrogen & & \\
\hline $100 \mathrm{~kg}$ urea ha ${ }^{-1}$ & 3.83 & 2.55 & 248.67 & 28.92 & 31.83 \\
\hline $200 \mathrm{~kg}$ urea ha ${ }^{-1}$ & 3.43 & 2.71 & 202.30 & 26.29 & 23.75 \\
\hline
\end{tabular}

Keterangan : angka yang diikuti huruf yang sama pada kolom yang sama tidak berbeda nyata pada uji Selang Berganda Duncan (DMRT) pada taraf 5\%

Panjang umbi per tanaman bukan termasuk peubah yang diharapkan dalam produksi talas belitung karena ukuran umbi yang dapat dijual ke pasar berdasarkan diameter umbi (minimal $5 \mathrm{~cm}$ ). Berdasarkan Tabel 8 diketahui bahwa tanaman dengan perlakuan jarak tanam 1 $\mathrm{m} \times 0,5 \mathrm{~m}$ menghasilkan panjang umbi $1.78 \mathrm{~cm}$ lebih baik daripada jarak tanam $1 \mathrm{~m} \times 1 \mathrm{~m}$. Hal ini 
diduga karena adanya kompetisi antar tanaman dalam penggunaan air, hara, dan cahaya pada jarak tanam yang lebih rapat sehingga menyebabkan perpanjangan akar. Menurut Gardner et al. (2008) salah satu cara akar mendapatkan hara untuk diangkut ke daun adalah melalui pemanjangan akar menuju sumber hara tersebut.

Peubah diameter dan panjang bonggol per tanaman serta bobot basah dan bobot kering brangkasan per tanaman hanya merupakan parameter tambahan untuk melihat produksi umbi talas belitung. Berdasarkan Tabel 8 diketahui bahwa perlakuan jarak tanam dan pupuk nitrogen serta interaksi kedua perlakuan tersebut tidak berpengaruh nyata terhadap peubah diameter dan panjang bonggol per tanaman serta bobot basah dan bobot kering brangkasan per tanaman. Hal ini diduga karena pupuk nitrogen mengalami leaching setelah aplikasi pemupukan. Berdasarkan Data BMKG dari Stasiun Klimatologi Klas 1 Dramaga, curah hujan pada saat aplikasi pupuk yaitu bulan Februari 2016 (610 mm) dan April $2016(558,2 \mathrm{~mm})$ tergolong tinggi sehingga diduga nitrogen tercuci oleh air hujan. Selain itu dapat diduga akumulasi fotosintat pada daun maupun umbi belum maksimal sehingga perlakuan pupuk nitrogen tidak berpengaruh nyata terhadap semua peubah panen. Menurut Lebot (2009) fotosintat terakumulasi maksimal pada daun tanaman talas belitung yang berumur 10-30 MST sedangkan pada umbi tanaman talas belitung yang berumur 36-45 MST.

Indeks Panen merupakan perbandingan bobot umbi dan bobot total brangkasan tanaman. Semakin tinggi nilai Indeks Panen maka hasil panen semakin baik. Berdasarkan Tabel 8 diketahui bahwa Indeks Panen tanaman talas belitung hanya berkisar 23-31 dengan Indeks Panen pada jarak tanam $1 \mathrm{~m}$ x $1 \mathrm{~m}$ lebih $26.48 \%$ daripada jarak tanam $1 \mathrm{~m} \times 0.5 \mathrm{~m}$ sedangkan perlakuan pupuk nitrogen $100 \mathrm{~kg}$ urea ha ${ }^{-1}$ lebih baik $34.02 \%$ lebih baik daripada perlakuan $200 \mathrm{~kg}$ urea ha ${ }^{-1}$. Rendahnya nilai Indeks Panen diduga karena pengisian umbi belum optimal dan waktu panen terlalu muda (5 bulan setelah tanam) sedangkan secara umum tanaman ini dipanen pada 10-12 bulan setelah tanam. Menurut Lebot (2009) akumulasi fotosintat maksimal umbi talas belitung pada umur tanaman 36-45 MST atau 9-11 bulan setelah tanam.

\section{KESIMPULAN}

Jarak tanam $1 \mathrm{~m}$ x $1 \mathrm{~m}$ menunjukkan hasil yang lebih baik daripada jarak tanam $1 \mathrm{~m} \times 0,5 \mathrm{~m}$ terhadap pertumbuhan dan produksi talas belitung pada peubah daya tumbuh, jumlah daun hijau, jumlah umbi per tanaman serta bobot basah umbi per tanaman. Perlakuan pupuk nitrogen $100 \mathrm{~kg}$ urea ha $^{-1}$ menunjukkan hasil lebih baik daripada $200 \mathrm{~kg}$ urea $\mathrm{ha}^{-1}$ terhadap pertumbuhan talas belitung pada peubah jumlah daun hijau, tinggi tanaman, dan diameter batang. Interaksi perlakuan jarak tanam dan pupuk nitrogen tidak memberikan pengaruh nyata terhadap pertumbuhan dan produksi talas belitung.

\section{DAFTAR PUSTAKA}

Adil, W.H., Sunarlim, N., Roostika, I. 2006. Pengaruh tiga jenis pupuk nitrogen terhadap tanaman sayuran. Biodiversitas. 7(1):77-80.

Agbede, T.M. 2008. Nutrient availability and cocoyam yield under different tillage practices. Soil \& Tillage Research. 99:4957.

Agegnehu, G., Nelson, P.N., Bird, M.I. 2016. The effects of biochar, compost, and their mixtue and nitrogen fertilizer on yield and nitrogen use efficiency of barley grown on a nitiol in the highland of Ethiopia. Science of Total Environment. 2016:1-11.

Ahmed, N., Razaq, M., Alam, H., Salahudin. 2016. Reponse of french bean cultivar to plant spacing under agroclimatic condition of Baffa. Journal of Notrheast Agricultural University. 23(1):16-19.

Anggarwulan, E., Solichatun, Mudyantini, W. 2008. Karakter fisiologi kimpul (Xanthosoma sagittifolium (L.) Schott) pada variasi naungan dan ketersediaan air. Biodiversitas. 9(4):264-268.

Arisandy, O.M.P., Estiah, T. 2016. Beras Tiruan Berbasis Tepung Kimpul (Xanthosoma sagittifolium): Kajian Pustaka. Jurnal Pangan dan Agroindustri. 4(1):253-261.

Barchia, M.F. 2009. Agroekosistem Tanah Mineral Masam. Yogyakarta (ID): Gadjah Mada University Press.

Budiastuti, M.S. 2000. Penggunaan triakontanol dan jarak tanam pada tanaman kacang hijau (Phaseolus radiatus L.). Agrosains. 2(2):59-63.

Decoteau, D.R. 2005. Principles of Plant Science: Enviromental Factors and Technology in 
Growing Plants. New Jersey (US): Pearson Education Inc.

Fitria, M. 2007. Pengaruh dosis pupuk dan jarak tanam terhadap pertumbuhan dan produktivitas tanaman buru hotong (Setaria italica (L.) Beauv). [Skripsi]. Institut Pertanian Bogor. Bogor.

Gardner, F.P., Pearce, R.B., Mitchell R.L. 2008. Fisiologi Tanaman Budidaya. Jakarta (ID): UI Press.

Hardjowigeno, S. 2003. Ilmu Tanah. Jakarta (ID): Akademi Pressindo.

Indrasti, D. 2004. Pemanfaatan talas belitung (Xanthosoma sagittifolium) dalam Pembuatan Cookies. [Skripsi]. Institut Pertanian Bogor. Bogor.

Jackix, E.A., Monteiro, E.B., Raposo, H.F., Farfán J.A. 2013. Cholesterol reducing and bileacid binding properties of taioba (Xanthosoma sagittifolium) leaf in rats fed a high-fat diet. Food Research International. 51:886-891.

Jatmiko, G.P., Estiah, T. 2014. Mie dari umbi Kimpul: Kajian pustaka. Jurnal Pangan dan Agroindustri. 2(2):127-134.

[KEMENTAN] Kementerian Pertanian. 2014. Statistik Konsumsi Pangan Tahun 2014. Pusat Data dan Informasi, Sekretariat Jendral, Kementerian Pertanian. [internet]. [diunduh 2016 Mar 28]. Tersedia pada http://www.pusdatin.setjen.pertanian.go.id /statistika-202-statistik-pertanian2014.html.

Latifa, I.C., Anggarwulan, E. 2009. Nitrogen content, nitrate reductase activity, and biomass of kimpul (Xanthosoma sagittifolium) on shade and nitrogen fertilizer variation. Nusantara Bioscience. 1:65-71.

Lebot, V. 2009. Tropical Root and Tuber Crops: Cassava, Sweet Potato, Yams, and Aroids. London (UK): CABI Publishing.

Lim, P.O., Kim H.J., Nam, H.G. 2007. Leaf senescence. Annual Rev. Plant. Bio. 58:36-115.
Manner, H.I., 2011. Farm and forestry production and marketing profile for Tannia (Xanthosoma spp). In: Specialty Crops for Pacific Island Agroforestry [ed. Elevitch, C.R.]. Permanent Agriculture Resources (PAR). Holualoa, Hawaii, USA.

Munawar, A. 2011. Kesuburan Tanah dan Nutrisi Tanaman. Bogor (ID): IPB Press.

Munson, R.D. 1998. Principle of plant analysis. In: Handbook of Reference Methods for Plant Analysis. Kalra Y.P., editor. Soil and Plant Analysis Council, Inc, Boca Reton, US.

Nurshanti, R. 2008. Pengaruh umur bibit dan jarak tanam terhadap pertumbuhan dan produktivitas tanaman buru hotong (Setaria italica (L.) Beauv). [Skripsi]. Institut Pertanian Bogor. Bogor.

Onyeka, J. 2014. Status of Cocoyam (Colocasia esculenta and Xanthosoma sagittifolium) in West and Central Afrika: Production, Household Importance, and The Threat from Leaf Blight. CGIAR Research Program on Roots, Tubers, and Banana (RTB), Lima, Peru.

Peraturan Pemerintah Republik Indonesia nomor 17 tahun 2015 tentang Ketahanan Pangan dan Gizi.

Pratama, A.A. 2010. Efisiensi penggunaan nitrogen pada padi (Oryza sativa L.). [Skripsi]. Institut Pertanian Bogor. Bogor.

Sandoval, J.S., Rodriguez, P.E. 2014. Xanthosoma sagittifolium (elephant ear). [internet]. [diunduh 2016 Mar 28]. Tersedia pada http://www.cabi.org/isc/datasheet/56989.

Welde, K., Grebemariam, H.L. 2016. Effect of different furrow and plant spacing on yield and water use efficiency of maize. Agricultural Water Management. 177(2016):215-220.

Wijaya, K.A. 2008. Nutrisi Tanaman sebagai Penentu Kualitas Hasil dan Resistensi Alami Tanaman. Jakarta (ID): Prestasi Pustaka Publisher.

Wiyono, S., Manuwoto, S. 2008. Penyakit Antraknosa pada Pepaya dan Potensi Pengendaliannya. Pusat Kajian Buah Tropika, LPPM-IPB, Bogor. 